\title{
ФІЛОСОФІЯ: НАУКА ЧИ СВІТОГЛЯД?
}

\section{Я.В. Шрамко}

Едмунд Гуссерль, працюючи на початку XX століття над своїм програмним твором «Філософія як строга наука», виходив із переконання, що «величні інтереси людської культури вимагають створення строго наукової філософії» ${ }^{1}$. В наш час багато хто розцінюе це твердження як дещо наївне. Проте Гуссерль лише відтворюе тут певне уявлення, яке ще донедавна вважалося майже очевидним, свого роду аксіомою, що не потребуе особливого обгрунтування. Так, наприклад, представники класичного німецького ідеалізму, розглядаючи себе в якості повноправних філософських спадкоемців Іммануіла Канта, анітрохи не сумнівалися в науковому характері філософії взагалі і своїх філософських систем зокрема ${ }^{2}$. Фіхте, розробляючи своє «науковчення», ставив за мету «підняти філософію до рівня науки» ${ }^{3}$. Шеллінг вважав, що філософія $\epsilon$ «найвищою і головною наукою» ${ }^{4}$. Гегель у передмові до другого видання «Енциклопедії філософських наук» стверджував, що єдине, до чого він прагне «у своїх філософських дослідженнях це наукове пізнання істини» 5 .

\footnotetext{
${ }^{1}$ Гуссерль Э. Философия как строгая наука // Избранные работы. - М.: Террнтория будущего, 2005 . - C. 191.

${ }^{2}$ Парадитмально в цьому відношенні звучать наступні слова Фіхте: «Філософія е наука; в цьому настільки ж співпадають всі визначення філософії, наскільки вони різняться щодо визначення предмету піеі науки» (Фuхте И.Г. О понятии наукоучения, или так называемой философил. 1794// Сочинения в двух томах. Т. 1. - СПб.: Мифрнл, 1993.- С. 14.).

${ }^{3}$ Фихте И.Г. Факты сознания. Назначение человека. Наукоучение. - Мн.: Харвест, M.: ACT, 2000.- C.274.

${ }^{4}$ Див.: Пелаине Ф.В.Й. Спстема транспендентального пдеализма // Сочинения в двух томах - Т. 1. - М.: Мысль, 1987.- - .234.

${ }^{5}$ Гегель Г.В.Ф. Энциклопедия философских наук. - Т. 1. - Наука логики. - М.:
}

Актуальні проблеми духовності:

3б. наук. праць / Рет.: Я.В. Шрамко

Вин. 11. - Кривий Ріг, 2010, $98-112$ 
Однак, чим більш піднесеним був науковий пафос спекулятивних ідеалістичних концепцій, тим більш разюче він контрастував з їх абсолютно антинауковим змістом ${ }^{6}$. Як результат, фіхтевський проект науковчення досить швидко зазнав фіаско, Шеллінг у розробці своधї філософської концепції так і не зміг піти далі попередніх начерків, а система Гегеля увійшла в мертвий клінч $з$ його діалектичним методом. Пізніша спроба прищепити спекулятивний філософський ідеалізм неогегельянського зразку на англійському грунті («абсолютний ідеалізм» Бредлі, Бозанкета, Гріна, Мак-Таггара та інших) також виявилася безуспішною, наочно продемонструвавши безперспективність умоглядного конструювання реальності на основі принципів чистої логіки.

Після того як спекулятивний філософський ідеалізм зайшов у глухий кут, різними мислителями були здійснені чисельні спроби знайти вихід 3 цього глухого кута на шляхах кардинальної перебудови наявних філософських концепцій або навіть перегляду самого поняття філософії. Серед таких спроб найбільш значними й системними виявилися програми першого позитивізму та неокантіанства. Незважаючи на те, що в цілому ці програми були орієнтовані на науковий підхід до філософії, саме в них, дещо парадоксальним чином, визріває ідея розведення та навіть протиставлення філософії і науки. Так, засновник позитивізму Огюст Конт не вносить філософію до своєї класифікації наук, до яких він зараховуе математику, астрономію, фізику, хімію, фізіологію (біологію), соціальну фізику (соціологію), і проголошуе завдання «очищення» науки від метафізики ${ }^{7}$. 3 іншого боку, культурологічний релятивізм основних представників Баденської і Марбурзької шкіл неокантіанства по суті ставить філософію в один ряд з такими явищами культури, як міфологія, релігія, мистецтво і, як наслідок, виводить філософію за межі строго наукового знання ${ }^{8}$.

\footnotetext{
Мысль, 1974.-С.57.

${ }^{6}$ Основний недолік спекулятивного ідеалізму точно діагностував Кант в своїй «Заяві $з$ прнводу науковчення Фіхте», вказавши, що спстема останнього «являе собою лите логіку, яка зі своімп принципами не досягае матеріального моменту пізғання і як чиста логіка відволікаеться від його змісту. Спроба внчленити з неі реальний об'єкт є марною і тому нездійсненною справою» (Каяm. И. Трактаты и ппсьма. - M.: Наука, 1980.-C.625.).

7 Див.: Cmепин B.C. Философия науки. Общие проблемы.- М.: Гардарики, $2007 .-$ C. 15 .

${ }^{8}$ Показовим у цьому відношенні е наступне твердження В. Віндельбанда: «Факти історії вимагають утримання від . . безумовного підпорядкування філософії поняттю науки. Неупереджений потляд історика визнае філософію складним і мінливим культурним явищем, яке неможливо просто втиснути в деяку схему чи ру-
} 
Починаючи з другої половини XIX ст., ідея обгрунтування і самовизначення філософії шляхом іï рішучого протиставлення будь-якій діяльності, яка може бути визнана науковою, починає набувати все більшого поширення. Ця ідея знаходить свое вираження, наприклад, в наступному вислові М.Бердяєва, сформульованому у притаманній йому яскравій полемічній манері:

Філософія ні в якому смислі не $є$ наукою і ні в якому смислі не повинна бути науковою. Майже незрозуміло, чому філософія забажала бути схожою на науку, стати науковою. Не повинні бути науковими мистецтво, мораль, релігія. Чому ж філософія мае бути науковою? ${ }^{9}$.

Можна стверджувати, що такий погляд на природу філософії, з тими чи іншими застереженнями, отримав на сьогодні широке визнання з боку представників найрізноманітніших філософських напрямів.

Серед сучасних російських авторів цю позицію послідовно відстоюе О.Л. Нікіфоров, який у ряді публікацій сформулював їі з усією можливою визначеністю, а також виклав ряд аргументів на $11 ̈$ користь ${ }^{10}$. Він справедливо зауважує, що в радянській філософській традиції уявлення про науковість філософії вкоренилося перш за все «завдяки тривалому і монопольному пануванню марксизму» ${ }^{11}$, коли марксистська філософія як «істинно наукова» протиставлялася всіляким «ненауковим буржуазним (ідеалістичним) філософським системам». У цьому відношенні - як своєрідна природна реакція на багаторічне засилля «едино вірного вчення» - виступ О.Л. Нікіфорова $е$ цілком зрозумілим і його позиція багато в чому виглядає доволі обгрунтованою. Проте, на наш погляд, О.Л.Нікіфоров разом з водою вихлюпуе тут і дитину. Тому варто докладніше зупинитись на тих аргументах, які він висувае проти науковості філософіiі ${ }^{12}$, з тим, щоб звернути увагу на їх слабкі сторони. Оскільки точка зору О.Л. Нікіфорова на поставлену проблему є

брику» (Виндельбанд В. Вказ.тв.-С.25.).

${ }^{9}$ Бердяее Н. Смысл творчества // Философия свободы. Смысл творчества. М.: Правда, 1989.-С.264.

10 Див., перш за все, статтю Нижифорое А.Л. Является ли философия наукой? // Философские науки. - 1989. - №6.- С.53, а також Нижифоров A./. Философня как личный опыт // Заблуждающийся разум? Многообразие вненаучного знания. - М., 1990. - С.311-312. Ми, в основному, будемо посилатися на викладення та обгрунтування вказаної позиції в роботі: Никифоров А.Л. Природа философин: основы фнлософии. - М.: Идея-Пресс, 2001.

${ }^{11}$ Нижифіоров А..Л. Природа философии: основы философии. - М.: Идея-Пресс, 2001. - C. 17.

12 Див.: Там же.-С. 19-25. 
значною мірою репрезентативною, то нижче ми піддамо її детальному аналізу.

Так, О.Л.Нікіфоров відзначає, що положення науки обов'язково повинні підтверджуватися фактами, в той час як філософія, на його погляд, демонструе «байдужість до підтвердження». Тут, певно, ми маємо не зовсім правомірне ототожнення наукового знання 3 тим, що може бути названим «частними емпіричними науками». Твердження останніх мають безпосередньо «предметний (фактуальний) зміст», тобто прямо відносяться до світу матеріальних предметів (подій, процесів тощо), й такі твердження цілком природно перевіряти на відповідність фактичному стану справ в матеріальному світі. Але в філософії ситуапія дещо інша.

Філософські висловлювання не мають «конкретно-предметної» спрямованості i, в цьому плані, філософія дуже відрізняється, скажімо, від фізіології або географії. Проте, якщо ми будемо на цій підставі відмовляти філософії в науковості, то так само доведеться вчинити і 3 математикою. Математичні рівняння та теореми геометрії не тільки не потребують підтвердження фактами, але й передбачають неможливість такого роду «підтвердження». Математичні твердження відносяться не до «фактуальної реальності», а до дійсності особливих абстрактних об'ектів (чисел, класів, геометричних фігур тощо), які за самою своєю природою не мають просторово-часового буття і $\mathbf{e}$ принципово неспостережуваними. Було б вкрай нерозумно і просто методологічно некоректно намагатися «підтвердити» теорему Піфагора шляхом вимірювання сторін у накресленому на дошці або на аркуші паперу прямокутному трикутнику, хоча б тому, що ніякий «фактичний» трикутник не $е$ трикутником у строгому смислі. Однак, ніхто не буде сперечатися 3 тим, що арифметичні, алгебраїчні і геометричні теорії не просто е науковими, але й задають взірець, на який певним чином орієнтуються всі науки.

Аналогічним чином обстоять справи 3 критеріями можливої перевірки або спростування, а також 3 проблемою наукових методів, про що також веде мову О.Л. Нікіфоров. Можна цілком погодитися 3 тим, що «твердження філософії не можуть бути емпірично перевірені і спростовані», і що «філософ не проводить спостережень, не ставить експериментів, не збирає фактів». Однак, це не виводить філософію за межі науки, оскільки ці зауваження в тій самій мірі справедливі й для математики, що жодним чином не підривае її наукового статусу. Як було зазначено вище, такого роду аргументи спрацьовують лише у випадку тлумачення науки у вузькому значенні слова «science», на 
кшталт природознавства і конкретних соціальних наук. Про можливість емпіричної перевірки і спростування, а також про використання емпіричних методів дослідження доречно говорити лише відносно наук, предметом вивчення яких є конкретні області матеріальної (емпіричної) реальності. У будь-якому разі очевидно, що філософія до такого роду наук не належить.

Хоча зазначені аргументи й не спростовують можливості філософії як науки взагалі, вони виявляють специфіку суто філософських суджень, які за самою своєю природою подібні до суджень математики: вони не передбачають підтвердження фактами, не підлягають емпіричній перевірці чи спростуванню, для їх отримання неможливо використовувати емпіричні методи дослідження (спостереження, вимірювання, експеримент). Більш того, ці аргументи цілком можуть бути використані проти претензій деяких (квазі)філософських систем на надання нам фактуального знання про емпіричний світ. Наприклад, такі квазіфілософські твердження як «Природа людини незмінна», або «В основі розвитку світу лежить саморозвиток абсолютного духу» ${ }^{13}$ слід визнати «незаконними», саме на підставі їх яскраво вираженого дескриптивного i, по суті, фактуального характеру. Подібні декларації претендують на те, на що філософські судження не можуть і не повинні претендувати - на опис (гіпотетичного) устрою певних об'єктів нашого світу або навіть всього світу в цілому. Такого роду судження $е$ не більш філософськими, ніж судження «Число планет Сонячної системи 3 необхідністю дорівнюе 7» або «В основі світу лежить число 1»-математичними. На таку схожість філософії і математики вказуе також і О.Л. Нікіфоров, зазначаючи, що «постулати філософських систем, як і аксіоми математичних теорій, не передбачають емпіричного обгрунтування» ${ }^{14}$. На наш погляд, ця схожість має зовсім не випадковий характер.

Щодо інших критеріїв науковості, які розглядає О.Л.Нікіфоровнаявність сталих парадигм, існування загальнозначимих проблем, вироблення специфічної наукової мови (наукової термінології), то можна стверджувати, що філософія значною мірою відповідає цим критеріям. Навіть побіжний погляд на історію філософії дозволяє виділити певні філософські парадигми, що переважали у той чи інший період іï розвитку (якщо не брати до уваги різного роду маргінальних течій, яких завжди вистачає в будь-якій галузі наукового знання ${ }^{15}$ ). Так са-

\footnotetext{
13 Див.: Там же.-С. 21.

${ }^{14}$ TaM же - C. 23.

${ }^{15} \mathrm{Ha}$ наш погляд, не варто перебільшувати значення того кочевидного факту»,
} 
мо у філософії зберігаеться й певний набір традиційних проблем, які іноді навіть називають «вічними». Має філософія й власну ретельно розроблену термінологію, володіння якою також відрізняе професійного філософа від дилетанта.

В цілому, ми не поділяємо позицію О.Л. Нікіфорова, який обмежує компетенцію філософії сферою простої думки, вважаючи, що філософські системи представляють лише «думки філософа про світ і про себе ${ }^{16}$. Тим самим статус філософії значно понижується, оскільки виявляється, що філософські судження не мають характеру всезагальності і необхідності, які притаманні науковим твердженням, тобто судженням, що виражають знання. Але, навіть якщо філософія не може претендувати на те, щоб давати нам емпіричне знання, це не означає, що філософія не в змозі продукувати знання як таке. Навпаки, філософи завжди прагнули досягти істини, а значить - здобути знання в найточнішому смислі цього слова ${ }^{17}$. У цьому відношенні філософія нічим не відрізняється від інших наук. Причому філософія зовсім не являе собою якусь особливу «науку наук» (або «царицю всіх наук»), а є такою самою наукою, як і всі інші науки. Звісно, філософія має свою специфіку, обумовлену, насамперед, предметом $\dddot{11}$ дослідження, але так само свою специфіку має і будь-яка інша наука, будь то фізика, історія або математика.

Найбільш розробленою і впливовою альтернативою наукового розу-

по «філософія у сучасному світі - пе розмаїтий конгломерат найрізноманітнімих шкіл, течій та напрямків - феноменологи, екзистенпіалісти, герменевтики, аналітичғі філософи, фiлософп науки, послідовники пізньото Віттенштейна, постмодер-

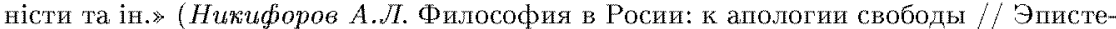
мология и философия науки. - 2010. - № 1. - С. 127.). Пей факт зовсім не свідчить про «безпараднтмальність» сучасної фiлософі1. По-перше, у будь-якій «нормальній науці» завжди співіснують різноманітні школи та напрямки. Аналогічним чином (i $з$ тим сампм успіхом) можна стверджувати, по математика у сучасному світі це розмаїтий конгломерат найрізноманітніших шкіл, течій та напрямків - універсальна алтебра, теорія алгебраїчних систем, Евклідова геометрія, геометрія Лобачевського, класпчна теорія мнокин, конструктивна математика, нестандартний аналіз тощо. По-друге, наведений перелік демонструе явні ознаки кпомноження сутностей». Без особливого перебільшення, все розмаїття існуючнх у сучасній філософії шкіл та течій можна звести до двох основних (панівних) парадигм, які представлені ағалітичною філософіею та феноменолотічним напрямком.

${ }^{16}$ Нижифорое A.Л. Природа фнлософии: основы философии. - М.: Идея-Пресс, 2001. - C. 54 .

${ }^{17}$ В ділому, цей смисл задаеться тим розумінням, що кожне знання може бути виражене за допомогою обруунтованих істинних висловпювань, пор.: Нижифоров A./. Анализ понятия «знание»: подходы п проблемы // Эпистемология п фплософия науки. - 2009.-N23.- C.61-73. 
міння філософії виступае її тлумачення як особливого різновиду (або типу) світогляду. У сучасній російській та українській філософії це тлумачення набуло характеру мало не загального місця, свого роду трюїзму, який в тому чи іншому формулюванні увійшов до переважної більшості вузівських підручників із загального курсу філософії: «Філософія - теоретично осмислений світогляд» ${ }^{18}$, «Філософія [...]теоретичний світогляд, вчення, яке прагне осягнути всезагальне у світі, людині і суспільстві» ${ }^{19}$, «Філософія - це система основоположних ідей у складі світогляду людини і суспільства» ${ }^{20}$, «Філософія - система поглядів на світ, суспільство, місце Людини в світі та суспільстві [...]. Отже філософія здійснюе функцію світогляду» ${ }^{21}$. На цьому ж наголошуе і О.Л. Нікіфоров:

Філософія є різновидом світогляду. У цьому твердженні немає нічого нового. Практично всі наші філософи згодні $з$ тим, що філософія є раціональним систематичним світоглядом ${ }^{22}$.

Однак такий погляд на філософію, попри всю свою звичність, виявляється, при більш детальному розгляді, не таким вже й беззаперечним.

Перш за все, слід зазначити, що ідея визначення філософї̈ через поняття світогляду з'явилася порівняно недавно, як і саме поняття світогляду. Як зауважуе М. Хайдеггер, термін «світогляд» (Weltanschauung) має суто німецьке походження і вперше зустрічається в «Критиці здатності суджень» Канта ${ }^{23}$, хоча вживається там не в сучасному «систематично-глобальному» значенні, а лише як особливий випадок «споглядання» (Anschouung), а саме - як «споглядання світу», «про-

\footnotetext{
${ }^{18}$ Bведение в философпю: Учеб́. пособпе для вузов / Авт. колл.: Фролов И.Т. и др. - З-е изд., перераб. и доп. - М.: Республика, 2003.- С. 18 . В першому виданні цього підручника вказане означення формулюеться дещо інакше: «Філософія теоретично сформульований світогляд» (Веедение в философию / Под общей ред. И.Т. Фролова. В 2 ч. - М.: Политиздат, 1989.- Ч. 1. - С. 40.).

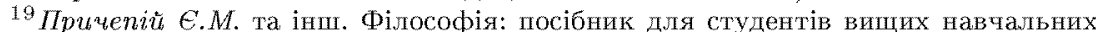
закладів. - К.: Видавничий центр «Академія», 2001.

${ }^{20}$ Спиркик A.Г. Фплософпя: Учебнпк. - M.: Гардарпкп, 2000.

${ }^{21}$ Філософiя: Підручник / За заг. ред. В.Г. Кременя, М.І. Горлача. - Вид. трете, перер. та доп. - Харків: Прапор, 2004. - С.23-24.

${ }^{22}$ Никифоров A.Л. Вказ. тв.- С. 27.

${ }^{23}$ Кант И. Критика способности суждения // Сочинения на немепком и русском языках. - T.IV. - М.: Наука, 2001. - С.278-279. Цікаво, шо в цьому місді термін Weltanschauung традипійно перекладаеться російською як «созерпание мпра» (а не «мпровоззрение»), шо впдаеться доволі адекватним, внходячи з розуміння, в якому наведений термін використовуеться Кантом.
} 
сте сприйняття природи в найбільш широкому смислі» ${ }^{24}$. Пізніше це поняття взяли на озброєння романтики (Жан Поль, А.В.ПІлегель, Новаліс) і представники німецького ідеалізму (Фіхте, Шеллінг), які надали йому змісту, близького до сучасного ${ }^{25}$ розуміння світогляду. В цьому зв'язку можна також згадати Ф. Шлейєрмахера, який у своïx лекціях з педагогіки 1813 р. обгрунтував розуміння світогляду як особливого роду «споглядання універсуму» в рамках «спекулятивного природознавства і науково витлумаченої історії» ${ }^{26}$. До кінця XIX століття слово «світогляд» (або його аналоги) поширилось не тільки в німецькій, а й у багатьох інших мовах, зокрема-російській ${ }^{27}$. Так, B.I. Вернадський, у циклі лекцій, прочитаному в Московському університеті в 1902-1903 рр. абсолютно вільно оперуе цим поняттям, не вважаючи при цьому за необхідне якось його додатково роз'яснювати, більше того, цілком природно використовуе словосполучення «науковий світогляд» 28 .

Приблизно в той самий час деякі автори висувають ідею всеосяжного «світоглядного вчення» (Weltanschauungslehre), і тут у першу чергу слід згадати позитивістськи орієнтованого австрійського філософа Г. Гомперца, який здійснив спробу всебічної розробки такого вчення, покликаного, на його думку, замінити традиційну теоретичну філософію, основними складовими якої виступають метафізика і теорія пізнання. В якості головного завдання свого Weltanschauungslehre Гомперц бачить «відтворення в розумі вже встановлених і впорядкованих фактів ${ }^{29}$, точніше - «створення несуперечливої системи всіх тих ідей,

\footnotetext{
${ }^{24}$ Хайдеzгер M. Основные проблемы феноменологин. - СПб.: Выспая релитиозно-философская школа, 2001.- С.5, і далі «Також вживають це слово Гете й Олександр фон Гумбольдт». Цікаво, по Хайдеггер у пьому творі, вслід за Гуссерлем, проводить пітке розрізнення між «науковою філософіею» та «світотлядною філософіею».

253 словами Хайдегтера, світогляд у цьому смпслі означае «самостійно здійснюваний, продуктивний i, таким чином, усвідомлений спосіб осягнути і пояснити ділокупність сущото» (Хайдеzгер M. Вказ. тв.- - С.6.).

26 Див.: Mittelstraß $J .$, Hg.: Enzyklopädie Philosophie und Wissenschaftstheorie, 4 Bde. - Stuttgart: Metzler, 1995. - Bd.4.-C.652.

27 До інштх мов дей термін прпйтов 3 німецької або пляхом словотворчого калькування, тобто прямого «поморфемного» перекладу: «світ-огляд» (укр.), «миpo-воззренne» (poc.), «world-view» (amrл.), «cosmo-visión» (icn.), «świato-pogląd» (польськ.), або ж шляхом безпосереднього запознчення спова Weltanschauung, як де має міспе у франпузькій, італійській, портутальській та пизпі інптх мов.

${ }^{28}$ Вериадский В.И. Очерки по пстории современного научного мировоззрения 1902-1903 гт. // Вернадский В.И. Избранные труды по истории науки. - М.: Наука, 1981. - C. 32-172.

${ }^{29}$ Gomperz H. Weltanschauungslehre. - Jena und Leipzig: Eugen Diederichs, 1905.
} 
що використовуються як окремими науками, так і практичним життям для відтворення фактів» ${ }^{30}$. Розв'язання цього завдання він шукає на шляхах послідовного емпіризму, який називає «патемпіризмом».

Проте дійсно вирішальний поворот здійснюе Вільгельм Дільтей, обгрунтувавши особливе «вчення про світогляд», на основі якого він сподівався поєднати факт розмаїття філософських систем 3 їх претензіями на всезагальність i, таким чином, виробити нове розуміння «сутності філософії». Центральними поняттями концепції Дільтея, що викладена, зокрема, в його роботі «Сутність філософії» ${ }^{31}$, виступають поняття життя і світу. Світ оточуе людину в якості певного «наочного цілого» і в процесі його взаємодії з людським життям виробляються особливого роду інтерпретації дійсності - світогляди, які прагнуть виразити «смисл і значення» цього світу. «Вся земля покрита, неначе строкатим сплетінням незліченних форм, життєбаченнями, художніми виразами світорозуміння, релігійно-визначеними догмами, філософськими формулами» ${ }^{32}$. Поезію, релігію і філософію об'еднуе деякий загальний предмет, точніше, загальне надзавдання - наблизити людство до розкриття «світової та життєвої загадки». У ході вирішення цього завдання відбувається становлення різних форм «життебачень» і світобачень, при цьому, філософія (метафізика) представляе собою особ́ливий тип світогляду, характерними рисами якого $є$ прагнення до обгрунтованості, понятійності та загальнообов'язковості. На думку Дільтея, протягом всієї історії філософії неухильно проявляеться одна й та сама тенденція - «охопити все існування в одне світоспоглядання» ${ }^{33}$. Таким чином, філософія виявляється втіленням особливої функції, «закладеної в структурі суспільства і необхідної для вдосконалення життя» ${ }^{34}$. Дільтей формулюе «основне положення» (Hauptsatz) свого вчення про світогляд таким чином:

Світогляди не $\epsilon$ продуктом мислення. Вони не виникають з чистої волі до пізнання. [.. . ] Вони випливають із життєвої поведін-

Вd. 1.- С. 14. Тут Гомперп розвивае ідею, озвучену раніпе Є. Дюрінгом, який вважав, що на зміну метафізпці мае прпйти певне «засноване виключно на реапьності світоглядне вчення» (Dühring E. Logik und Wissenschaftstheorie. - Leipzig: Fues's Verlag. 1878. - C.9.).

${ }^{30}$ Gomperz H. Op. cit. - C. 17.

з1 Дальтеи B. Сушность философип // Философия в систематическом изложенип. - М.: Издательский дом «Террпторпя будущего», 2006 - - С. 13-82.

32 дильтей B. Вказ. тв.- - .49

${ }^{33}$ TaM жеe. - C.67.

${ }^{34}$ Taм же. - C. 80 . 
ки, життєвого досвіду, зі структури нашої психічної ділісності ${ }^{35}$.

Нескладно побачити, що витлумачене таким чином поняття світогляду повністю вписується в загальне концептуальне поле філософії життя. Власне кажучи, саме цьому напрямку ми завдячуємо ретельною розробкою і наполегливим просуванням ідеї щодо світоглядної сутності філософії. Помітний внесок у розвиток і обгрунтування цієї ідеї внесли також неокантіанці Баденської школи, хоча у певному сенсі, неокантіанський погляд на співвідношення філософії та світогляду є протилежним дільтеєвському. Якщо за Дільтеем філософія похідна від світогляду i, за певних умов, породжуеться ним, то пізній Віндельбанд і ранній Ріккерт, розглядаючи світогляд у рамках свого «вчення про цінності», вважали його кінцевим продуктом філософії, яка «увінчує» світогляд і $є$ його найвищим проявом ${ }^{36}$. Зокрема Генріх Ріккерт писав:

Що світове ціле - предмет філософії і що вона в кінщевому рахунку прагне того, що ми називаємо малозначимим, але майже незамінним словом «світогляд», навряд чи хто зважиться заперечувати. [.. ] С Сітова проблема криеться . . . у відношенні $Я$ до «світу». Це відношення ми можемо також назвати відношенням суб'єкта до об'єкта і спробувати підвести під обидва пі поняття все те, що складає світ в більш широкому смислі слова. У такому випадку завдання філософії- показати, яким чином суб'єкт і об'єкт поєднуються в единому понятті про світ. Так званий світогляд і має дати відповідь на це питання, він повинен показати нам місце, яке ми займаємо у світовій цілісності ${ }^{37}$.

Таким чином, можна стверджувати, що на межі XIX-XX ст., перш за все саме завдяки популярності філософії життя і неокантіанської «філософії цінностей», а також величезному авторитету таких мислителів, як Дільтей і Ріккерт, проект «світоглядного обгрунтування» філософії привернув до себе загальну увагу і отримав значного поширення $^{38}$. Проте, дуже швидко виявилися серйозні недоліки такого погляду

\footnotetext{
${ }^{35}$ Diltey $W$. Zur Weltanschauungslehre. Abhandlungen zur Philosophie der Philosophie // Gesammelte Schriften. - Bd.8. - Leipzig/Berlin, 1931. - C. 86.

36 Див.: Wolters A.M. On the idea of worldview and its relation to philosophy $/ /$ P. Marshall et al (ed) Stained Glass. - University Press of America, 1983. - C. 17.

${ }^{37}$ Pиккерт $Г$. Науки о природе п науки о культуре.- М.: Респубпика, 1998. C. 15 .

${ }^{38}$ Водночас зауважимо, що уявлення про світотлядну природу філософії було взяте на озброення і марксизмом-ленінізмом, зокрема, радянського зразку, де во-
} 
на філософію. На деякі з них одразу ж звернув увагу Гуссерль ${ }^{39}$, наголосивши на необхідності розмежовувати погляд на філософію як на «культурне утворення» і як на явище, що має «об'єктивну значимість». На думку Гуссерля, послідовне проведення культурно-історнчного підходу до філософії має наслідком «крайній скептичний суб'єктивізм», а оскільки світогляд завжди являє собою «породження окремої особистості», то світоглядна філософія неминуче перетворюеться на щось на кшталт особистої проповіді або повчання, 3 якими «мудрець-філософ» звертається «до широких верств громадськості». Ці критичні зауваження Гуссерля здаються цілком обгрунтованими. Крім того, можна відзначити й інші слабкі місця «світоглядного підходу» до філософії. Перш за все, вразливим і навіть сумнівним видається зміст самого поняття світогляду. Неясний і невиразний характер цього поняття обумовлений нечіткістю і розпливчатістю самого феномену світогляду. Якщо виходити 3 «більш-менш загальновизнаного» ${ }^{40}$ визначення світогляду як сукупності «поглядів, оцінок, принципів, що визначають найзагальніше бачення, розуміння світу, місця в ньому людини, а також - життєві позиції, програми поведінки, дій людей» ${ }^{41}$, то не можна оминути очевидну двоїстість цього поняття. 3 одного боку, слід визнати, що світогляд має виражений індивідуально-особистісний характер, оскільки зазначені погляди, оцінки та принципи завжди належать кон-

но отримало ппрокі права громалянства. Власне кажучи, пе зовсім не $е$ дивншм, враховуючи, що в марксизмі поняття світопляду тісно пов'язане 3 поняттям ідеологіі. Ф. Енгельс у другій (1885р.) передмові до \&Антн-Дюрінгу» охарактернзував зміст цього твору як «більш-менш зв'язний виклад діалектичного методу і комуністичного світогляду». 3 тих пір в маркснзмі вважалося правнлом гарного тону, викладаючи вчення Маркса, вживати по відношенню до нього такі епітети як «пролетарський світоглядљ, «матеріалістичний світоплядь, «діалектико-матеріаліСтпчний світоглядљ $\mathrm{i}$ т.п. Сталін у своему знаменитому творі «Про діалектичнпй та історичний матеріалізм» канонізуе це уявлення за допомогою наступної лаконічної формули: «Діалектичний матеріалізм є світоглядом марксистсько-ленінської партії». Ця формула пражтично беззастережно приймалася потім офідійним радянсъким марксизмом протягом усього періоду його існування, доволі дивним тином поеднуючись з декларуванням «справжньої науковості» маркспстської фiлософії. Џікаво, по О.Л. Нікіфоров, вважаючи, по його виступ проти науковості філософіі у 1989 р. дозволив «закласти міну» під одержавлений маркспзм, не помічае, шо підкреслення світоглядного характеру філософії цілком гармонуе з ідеологічним трактуванням філософії в радянському маркспзмі-ленінізмі.

39 Див.: Гуссерль 9. Финософия как строгая паука // Избранные работы. - М. Издательский дом «Террптория будущего», 2005.- С. 221-240.

${ }^{40}$ Никифоров А.Л. Природа философип: основы философин. - М.: ИдеяшПресс, 2001. - C. 30 .

${ }^{41}$ Bведение в фплософпю: Учеб. пособне для вузов / Авт. колл.: Фролов И.Т. и др. - З-е изд., перераб. и доп. - М.: Республика, 2003.- С.8. 
кретній людині, що виступае їх носіем, а отже, носіем відповідного світогляду ${ }^{42} .3$ іншого боку, можна розглядати поняття світогляду в контексті виявлення деяких типових «поглядів, оцінок і принципів», притаманних певним групам людей на деякому історичному етапі, i в цьому смислі, говорити, наприклад, про «класовий світогляд», чи, скажімо, «світогляд епохи». Однак, в обох випадках світогляд виявляється занадто аморфним і розрізненим утворенням. Абсолютно неясним залишається і те, що може являти собою «найзагальніше бачення, розуміння світу і місця в ньому людини», яке надзвичайно важко зафіксувати як для індивідуального, так і «типізованого» світогляду.

У випадку буденного світогляду окремої людини такого роду «загальне бачення», як правило, виявляється деяким майже неоформленим (а часто й суперечливим) конгломератом положень, запозичених із найрізноманітніших областей, що включае загальнонаукові знання, релігійні або напіврелігійні переконання, всілякого роду передсуди, емоційні судження, засвоєні ще в дитинстві оцінки тощо. Скориставшись вдалим висловом О.Л. Нікіфорова ${ }^{43}$, можна сказати, що такий особистісний світогляд практично неможливо «виразно виразити». Але якщо тут ми стикаємося 3 чимось «невиразимим», то не зовсім зрозуміло, яким чином взагалі може відбуватися його «теоретичне осмислення», чим, на думку прихильників світоглядного підходу, і повинна займатися філософія.

Отже, доводиться визнати, що якщо філософія й має відношення до світогляду, то тоді вже до світогляду в узагальненому розумінні, притаманному тим чи іншим соціальним групам, або навіть цілим суспільствам. Проте онтологічний статус такого «узагальненого світогляду», а також характер його можливого співвідношення з філософією залишаеться значною мірою нез'ясованим. Якщо припустити, що він $е$ самостійним і самодостатнім утворенням, яке існуе ${ }^{44}$ поза межа-

\footnotetext{
42 He iснуе безособового, анонімного світогляду, в дентрі кожного світопляду стоїть пілком внзначенпй суб'єкт» (Никифоров A./. Вказ. тв.- С. 30.$)$.

${ }^{43}$ Taм жce.- - .27.

${ }^{44} \mathrm{Biдзнаяимо,} \mathrm{що} \mathrm{«модус} \mathrm{існування»} \mathrm{даної} \mathrm{форми} \mathrm{світопляду} \mathrm{потребуе} \mathrm{додатко-}$ вого уточненғя. Тут доречно згадати абстракдію «трьох світів» Готтлоба Фреге і Карла Поппера (див.: Фреге Г. Мысль: логическое исследование // Философия. Логика. Язык. - М., 1987; Поппер K.P. Объективное знание. Эволюпионный подход. - М.: Эдиторнал УРСС, 2002), згідно $з$ якою слід розрізняти (1) світ фізичних об'ектів і станів, (2) світ станів свідомості, тобто пспхічних станів і (3) світ об'ективного змісту мислення, утвореного, поміж іншим, змістом «наукових ідей, поетичних думок і творів мистептвав (Попnер К.P. Вказ. тв. - С. 108.). Зрозуміло, що індивідуальний світогляд кожної окремої пюднни належить - поряд із багатьма іншими вфактами свідомості» та психічними явищами - до другого світу.
} 
ми та незалежно від будь-якої філософії, то в такому разі завдання філософії очевидно має зводитися до адекватного вираження, кодифікування і теоретичного обгрунтування цього «типового світогляду» (тієї або іншої соціальної групи, епохи, суспільства тощо) ${ }^{45}$. Хоча таке тлумачення природи і завдань філософії видається навіть сумісним 3 поглядом на неї як на особливу науку, його не можна визнати адекватним, оскі.льки в результаті, з одного боку, філософія фактично перетворюється на дескриптивну («фактофіксуючу») дисципліну - свого роду розділ культурології, покликану виявляти, описувати та систематизувати наявні світоглядні системи. 3 іншого боку, це розуміння нав'язує філософії інструментальну роль «служниці світогляду», яка придатна, в кінцевому рахунку, лише для того, щоб виправдовувати і обгрунтовувати ці системи. Зрозуміло, що філософія, у дійсному розумінні, не є ані тим, ані іншим. Отже, серед прихильників «світоглядної сутності» філософії більш поширена позиція, яка ототожнюе філософію та світогляд, точніше підпорядковує поняття філософії поняттю світогляду. Згідно 3 цим, філософія не виражає світогляд як дещо зовнішне по відношенню до себе, а сама е світоглядом, точніше, особливим видом, або типом світогляду. Парадигмальне формулювання такого погляду на філософію зустрічаємо, наприклад, у Т.І. Ойзермана:

Філософія як особливого роду світогляд в рівній мірі $є$ концепцією світу і концепцією людини, знанням про те й інше і особливим способом узагальнення цього знання, що має значення соціальної, моральної, теоретичної орієнтації у світі поза нами і в нашому власному світі, виразом осмисленого відношення до дійсності і теоретичного обгрунтування џого відношення, що проявляється у людських рішеннях, поведінщі, духовному само-

На відміну від цього, жміжособистісний» (або «інтерсуб'єктивний») світогляд може існувати тільки в третьому світі. Але поб отримати таку можливість і такий статус, він обов'язково мае бути якимось чином об'ективований, тобто, знову ж таки, «зафіксований» або сформульований. Це, в свою чергу, утворюе окрему проблему, яка навряд чи може бути розв'язана однозначним чином. Дійсно, де і коли було сформульовано і послідовно викладено «світогляд епохи Відродження» або «світогляд давніх слов'ян»? Шо слід вважати аутентичним вираженням «пролетарського світогляду» - «Маніфест Комуністичної партії» К. Маркса і Ф. Енгельса або ж «Державність і анархію» М.А. Бакуніна?

45 «Завдання філософа полягае у тому, щоб провести порівняльний аналіз існуючих світоглядів i, якщо жоден 3 них не задовольняе, спробувати обгрунтувати новий світогляд. Таким чином, філософія виступае як самосвідомість або рефлексія світоглядуя (Сагатовсжй B.H. Философия антропокосмизма в кратком изложенин. - СПб.: Издательство Санкт-Петербургского государственного университета, 2005.). 
визначенні ${ }^{46}$.

Тут знов-таки викликае сумнів спроба представити світогляд в якості певного знання. Світогляд, звичайно, може вк.лючати елемент знання (перш за все, популярного характеру ${ }^{47}$ ), запозиченого з різних наук, однак значну частину нашого «загального погляду на світ і людину» все ж таки утворюють переконання, які в принципі неможливо звести до будь-якого знання. Слід погодитися з О.Л.Нікіфоровим, коли він закликає «усвідомити всі наслідки» твердження, що філософія $\epsilon$ різновидом світогляду і відзначае, шо «якщо спробувати розвинути погляд на філософію як на світогляд, то ми швидко з'ясуємо, що світогляд і наука - зовсім різні речі, тому визнавати філософію наукою і одночасно вважкати її формою світогляду означає впадати в суперечність» ${ }^{48}$. у кінцевому рахунку, ототожнення філософії з світоглядом неминуче приводить до висновку, що «до філософських тверджень поняття істини не застосовне» ${ }^{49}$, і отже, ці твердження виражають не знання, а деяку особисту «думку», тобто «індивідуальні оцінки та ставлення до світу ${ }^{50}$ окремих людей, які називають себе «філософами». Дійсно, якщо філософія є світоглядом, то, в першу чергу,-світоглядом того чи іншого філософа, який розробляе певну філософську систему, нехай навіть в цьому своєму індивідуальному світогляді йому і вдається якимось чином (наприклад, завдяки своїй геніальності) втілити «типовий світогляд» більш широких соціальних груп.

Таким чином, філософська система являе собою деякий індивідуальний смисловий контекст, в глибинному центрі якого лежать потаємні особисті переконання і уявлення філософа. Саме

\footnotetext{
${ }^{46}$ оизерман Т.И. Проблемы историко-философской науки. - М.: Мысль, 1982. C. 143 .

${ }_{47}$ Роль та місце науково-популярного знання у світогляді доволі вдало охарактеризував Людвік Флек: «Популярне знання ... - це знання не для спеціалістів, а для пироких кіл дорослих дилетантів, які мають загальну освіту. [...] Замість спедифічних обмежень, шо накладаються на мислення особливими доведеннями, попук яких супроводжуеться значними зусиллями, популярна наука оперуе спрощеннями, однозначними оцінками і наглядними живими образамн. Кінцевою метою популярної науки е світогляд (Weltanschaung) - особлива мислена конструкція (Gebilde), що виникає на основі емоційно забарвленої вибірки з різноманітних сфер популярного знання» (Флеж Л. Возникновение и развитие научного факта. Введение в теорию стиля мышления и мыслительного коллектива. - М.: Идея-Пресс, Дом интеллектуальной книги, 1999.- С. 136-137.).

${ }^{48}$ Hикифоров А.Л. Вказ. тв. - С. 27.

${ }^{49}$ Taм же.- С. 51

${ }^{50}$ там же.-С.54.
} 
ці особисті переконання і смаки пронизують весь світогляд філософа, включаються в якості суб'єктивних оцінок і характеристик в усі поняття і принципи його системи ... Кожна філософська система в цілому - це сукупність думок філософа про світобудову ${ }^{51}$.

Ці слова можуть служити прекрасною ілюстрацією того «крайнього суб'єктивізму», до якого неминуче призводить послідовний розвиток погляду на філософію як на особливий вид світогляду, і про який попереджав Гуссерль. За своєю сутністю такий суб'єктивізм має руйнівні наслідки для філософії в класичному розумінні, позбавляючи їі скільки-небудь твердого грунту і перетворюючи її на деяке «глибинносокровенне» таїнство, «обумовлене первинною інтуїцією філософа, що не підлягає поясненню і має бути прийняте як факт» ${ }^{52}$, на напівмістичні «роздуми над устроем універсуму і людини» 53 .

На нашу думку, цей «суб'єктивно-особистісний глухий кут», в який, рано чи пізно, заходять будь-які спроби світоглядного тлумачення філософії, переконливо свідчить проти такого тлумачення, а тому воно має бути відкинуте як неадекватне. Отже, справжне розуміння природи філософії можна досягнути лише з позицій іï обгрунтування як особливої науки, що має власний предмет, який дозволяє точно 3'ясувати її місце серед інших наук. Проте проблема визначення предметної області філософії виходить далеко за межі цієї статті і $є$ завданням окремого дослідження.

Надійила до редакиій 02 черкня 2010 р.

\footnotetext{
51 TaM жe.-C. $41,55$.

${ }^{52}$ Myдрагей Н.С. Рациональное и иррапиональное - философская проблема (читая А. Шопенгауэра) // Вопросы фнлософин. - 1994.-№ 9. - С. 82.

${ }^{53}$ Tам же. - C.78.
} 